\title{
Pengaruh Ukuran Bahan terhadap Rendemen dan Kualitas Minyalk Biji Pala (Myristica Fragrans Houtt) dengan Metode Soxhletasi
}

\author{
Andika Saranaunga, Meiske S. Sangia*, Dewa G. Katjaa*
}

aJurusan Kimia, FMIPA, Unsrat, Manado

\begin{tabular}{l} 
K A T A K U N C \\
\hline Ukuran bahan \\
Kualitas \\
Minyak biji pala
\end{tabular}

\begin{abstract}
A B S T R A K
Indonesia merupakan salah satu negara yang mempunyai berbagai jenis tanaman yang dapat dimanfaatkan oleh manusia, salah satunya ialah tanaman rempah-rempah. Di antara rempah-rempah utama Indonesia, pala merupakan salah satu rempah-rempah yang cukup tinggi nilainya sehingga perlu dikembangkan pemanfaatannya. Tujuannya menentukan rendemen dan kualitas minyak biji pala 60 mesh, 40 mesh, dan 20 mesh yang diambil dari kabupaten kepulauan talaud dengan metode soxhletasi. Metode yang digunakan adalah soxhletasi dengan pelarut $\mathrm{n}$-hexan. Kualitas minyak biji pala diperoleh dengan menguji bilangan asam, bilangan peroksida, bilangan ester, dan kelarutan dalam etanol 90\%. Hasil yang diperoleh dengan soxhletasi minyak biji pala rendemennya adalah 60 mesh (39,61\%), 40 mesh (37,52\%), dan 20 mesh (28,09\%). Bilangan asam 60 mesh (3,9777\%), 40 mesh (3,8967\%), dan 20 mesh (3,4928\%). Bilangan peroksida 60 mesh (0,0114\%), 40 mesh (0,0118\%), dan 20 mesh (0,0149\%). Bilangan ester 60 mesh (29,2059\%), 40 mesh (30,0777\%), dan 20 mesh (31,5288\%), dan kelarutan dalam etanol 90\% mendekati nilai yang ditetapkan SNI yaitu 1:1. Hasilnya menunjukkan bahwa rendemen minyak biji pala paling banyak adalah 60 mesh dan kualitas minyak terbaik adalah 20 mesh.
\end{abstract}

K E Y W O R D

Material size

Quality

Nutmeg seed oil
A B S T R A C T

Indonesia is a country which has various types of plants that can be utilized by humans one of plants is a spice plant. Among the main spices of Indonesia, nutmeg is one of the spices that is high enough value so that it needs to be developed utilization. The purpose of this research is to determine the rendemen and its quality of nutmeg seed oil of 60 mesh, 40 mesh, and 20 mesh taken from talaud islands by soxhletasi method with n-hexan solvent. The quality of nutmeg seed oil obtained by testing acid number, peroxide number, ester number, and solubility in ethanol $90 \%$. The results obtained with soxhletasi of nutmeg seed oil are 60 mesh (39,61\%), 40 mesh (37,52\%), and 20 mesh (28,09\%). Acid numbers are 60 mesh (3,9777\%), 40 mesh (3,8967\%), and 20 mesh (3,4928\%). Peroxide numbers are 60 mesh (0,0114\%), 40 mesh (0,0118\%), and 20 mesh (0,0149\%). The ester numbers are 60 mesh (29,2059\%), 40 mesh $(30,0777 \%)$, and 20 mesh $(31,5288 \%)$, and the solubility in ethanol is $90 \%$ close to the value set by the SNI that is $1: 1$. The results show that the rendement of 60 mesh nutmeg seed oil is most and the best quality oil is 20 mesh.
TERSEDIA ONLINE

01 Februari 2018

\section{Pendahuluan}

Indonesia merupakan salah satu negara yang mempunyai berbagai jenis tanaman yang dapat dimanfaatkan oleh manusia, salah satunya ialah tanaman rempah-rempah. Menurut Somaatmadja (1984) di antara rempah-rempah utama Indonesia, pala (Myristica fragrans Houtt) merupakan salah

*Corresponding author: Jurusan Kimia FMIPA UNSRAT, Jl. Kampus Unsrat, Manado, Indonesia 95115; Email address: andika.saranaung@yahoo.co.id Published by FMIPA UNSRAT (2018) 
satu rempah yang cukup tinggi dan telah secara luas diusahakan. Selain sebagai rempah-rempah, pala juga berfungsi sebagai tanaman penghasil minyak atsiri yang banyak digunakan dalam industri pengalengan, minuman dan kosmetik (Sunanto, 1993).

Rendemen dan mutu minyak dipengaruhi oleh beberapa faktor yaitu pra panen dan pasca panen. Kualitas minyak pala Indonesia telah distandarkan sesuai No 2388-2006 oleh Badan Standarsasi Nasional (BSN) (BSN, 2006).

Di Kabupaten Kepulauan Talaud pala sudah menjadi komoditi yang manjanjikan bagi petani karena nilai ekonomisnya yang cukup tinggi. Salah satu jenis pala di Kabupaten Kepulauan Talaud adalah jenis Myristica fragrans Houtt dengan bentuk buah pala yaitu bulat telur. Pada dasarnya masyarakat hanya mengolah buah pala khususnya bagian daging untuk dijadikan manisan pala dan juga anggur pala. Sedangkan bagian biji hanya dijual dan sampai saat ini belum diolah untuk diambil minyaknya.

\section{Material dan Metode}

\section{Alat dan Bahan yang Digunakan}

Alat yang digunakan yaitu alat soxhletasi, alat destilasi, alat evaporasi, oven, ayak, blender, desikator, timbangan analitik, gelas ukur 250 ml, corong pemisah, toples kaca, gelas piala 500 $\mathrm{ml}$,corong, kertas saring, cawan petri, statif, kapas, batu didih, erlenmeyer, labu saponifikasi, dan penangas air.

Bahan baku yang digunakan dalam penelitian yaitu biji pala yang diperoleh dari Kota Melonguane, Kecamatan Melonguane, Kabupaten Kepulauan Talaud, provinsi Sulawesi Utara. Untuk bahan kimia yang digunakan adalah n-Hexan, asam asetat glasial, kloroform, KI jenuh, natrium tiosufat 0,02M, indikator kanji 1\%, etanol netral, larutan fenolftalein, kalium hidroksida 0,1M, kalium hidroksida 0,5M, $\mathrm{HCl}$ 0,5M, dan etanol 90\%.

\section{Preparasi Sampel}

Sampel buah pala diambil, dibelah dan dipisahkan bagian biji, kemudian dikering anginkan selama 1 bulan. Setelah kering sampel diblender sehingga diperoleh suatu ukuran tertentu, lalu diayak dengan ayakan 20; 40; 60 mesh.

\section{Uji Kadar Air}

Ditimbang berat cawan petri terlebih dahulu, kemudian sampel biji pala dengan ukuran tertentu ditimbang masing-masing sebanyak 2 gram, lalu dimasukkan ke dalam cawan petri. Setelah itu dimasukkan ke dalam oven pada suhu $105^{\circ} \mathrm{C}$ selama 3 jam, setelah 3 jam dikeluarkan dari oven dan didinginkan dalam desikator selama 30 menit hingga mencapai suhu ruang, sehingga berat akhir ditimbang.

$$
\text { Kadar air }=\frac{b-(c-a)}{(c-a)} \times 100 \%
$$

\section{Ekstraksi}

Ekstraksi dilakukan dengan cara soxhletasi. Sampel minyak biji pala sebanyak 100 g dibungkus dengan kertas saring dan dimasukkan ke dalam ekstraktor soxhlet. Pelarut n-heksana sebanyak 500 $\mathrm{mL}$ dimasukkan ke dalam labu alas bulat. Kemudian alat soxhletasi dirangkai dengan kondensor. Ekstraksi dilakukan sekitar 6 jam. Selanjutnya ekstrak yang didapat dievaporasi menggunakan evaporator. Kemudian minyak biji pala yang diperoleh ditimbang beratnya dengan neraca analitik, dan dihitung rendemennya.

$$
\text { Rendemen }(\%)=\frac{\text { Berat ekstrak }(\mathrm{g})}{\text { Berat sampel }(\mathrm{g})} \times 100 \%
$$

\section{Bilangan Asam (Sudarmadji et al., 1997)}

Timbang 2 g minyak biji pala, dimasukkan ke dalam erlenmeyer, dan ditambahkan $5 \mathrm{ml}$ etanol netral. Dipanaskan sampai mendidih, dan digojog kuat-kuat untuk melarutkan asam lemak bebasnya. Setelah dingin, ditambahkan 10 tetes larutan fenolftalein sebagai indikator. Titrasi Iarutan tersebut dengan kalium hidroksida 0,1 M larutan $\mathrm{KOH}$ sampai berubah warna menjadi merah muda.

$$
\text { Bilangan asam }=\frac{\mathrm{ml} \mathrm{KOH} \mathrm{xM} \mathrm{KOH} \mathrm{xMr} \mathrm{KOH}}{\text { Berat sampel (g) }}
$$

\section{Bilangan Peroksida (Gunawan et al., 2003)}

Ke dalam erlenmeyer $30 \mathrm{~mL}$ dicampurkan asam asetat glasial dan kloroform (3:2), kemudian sampel minyak biji pala $5 \mathrm{~g}$ dimasukkan ke dalam larutan tersebut. Selanjutnya ditambahkan $\mathrm{KI}$ jenuh $0,5 \mathrm{~mL}$ dan dikocok sampai jernih. Setelah 2 menit dari penambahan $\mathrm{KI}$ ditambah $30 \mathrm{~mL}$ akuades. lod yang dibebaskan dititrasi dengan sodium thiosulfate $\left(\mathrm{Na}_{2} \mathrm{~S}_{2} \mathrm{O}_{3}\right)$ 0,02M hingga larutan berubah warna menjadi kuning. Setelah itu ditambahkan $0,5 \mathrm{ml}$ larutan indikator kanji $1 \%$ yang akan merubah warna larutan menjadi biru, titrasi kemudian dilanjutkan bersamaan dengan terus mengocok larutan hingga berubah warna menjadi biru muda yangmenandakan pelepasan iodine dari lapisan kloroform, lanjutkan titrasi dengan hati-hati hingga warna biru pada larutan hilang. Pengerjaan blanko dengan cara yang sama hanya tidak menggunakan sampel minyak.

Perhitungan nilai peroksida dilakukan dengan persamaan berikut:

$$
\text { Bilangan peroksida }\left(\frac{\mathrm{mol}}{\mathrm{kg}}\right)=\frac{\text { SxM }}{\text { Berat sampel }} \times 1000
$$

\section{Bilangan Ester (Sudarmadji et al., 1997)}

Pengujian blangko : labu diisi dengan beberapa potong batu didih, lalu tambahkan $50 \mathrm{ml}$ larutan kalium hidroksida 0,5M. Refluks dengan hati-hati diatas penengas air mendidih selama 30 menit setelah larutan mendidih. Diamkan larutan hingga menjadi dingin. Lepaskan kondensor refluks dan 
tambahkan 5 tetes indikator fenolftalein dan titrasi dengan $\mathrm{HCl}$ 0,5M sampai diperoleh perubahan warna. Selanjutnya dilakukan pengerjaan blanko dengan cara yang sama hanya tidak menggunakan sampel minyak.

Perhitungan :

Bilangan Penyabunan $=\frac{\left(\mathrm{V}_{1}-\mathrm{V}_{2}\right) \times \mathrm{M} \mathrm{HCl} \text { x Mr KOH }}{\text { Berat sampel (g) }}$

Bilangan ester $=$ Bilangan penyabunan-Bilangan asam

\section{Kelarutan dalam Etanol (SNI 06-2388-2006)}

Tempatkan $1 \mathrm{ml}$ minyak biji pala dan diukur dengan teliti di dalam gelas ukur yang berukuran 10 ml. Ditambahkan etanol 90\% setetes demi setetes.Kocoklah setelah setiap penambahan sampai diperoleh suatu larutan yang sebening mungkin pada suhu $20^{\circ} \mathrm{C}$. Bandingkanlah kekeruhan yang terjadi dengan kekeruhan larutan pembanding, melalui cairan yang sama tebalnya, bila larutan tersebut tidak bening.

\section{Hasil dan Pembahasan}

\section{Kadar Air}

Hasil pengujian kadar air serbuk biji pala dapat dilihat pada Gambar 1.

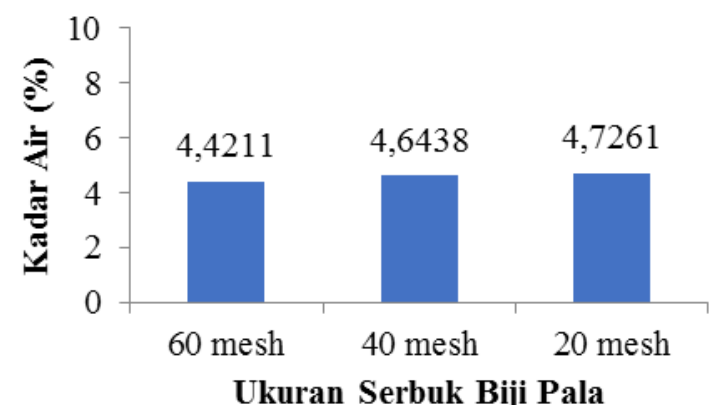

Gambar 1. Kadar air serbuk biji pala

Dari Gambar 1 terlihat bahwa kadar air biji pala menunjukkan bahwa ukuran serbuk tidak berpengaruh terhadap kadar air, dimana berada pada kisaran 4,4 dan 4,7.

Presentasi kadar air yang rendah atau di bawah $10 \%$ dapat mengoptimalkan ketahanan bahan pangan dari serbuk biji pala dalam waktu yang relatif lama dan tidak mudah rusak, sehingga aktivitas mikroorganisme pada bahan pangan dapat berkurang.

\section{Ekstraksi Minyak Biji Pala}

Jumlah minyak dalam biji pala dapat diketahui dengan cara mengekstraksi minyak di dalamnya. Minyak palabersifat non polar sehingga dapat larut dalam pelarut non polar. Pelarut non polar merupakan senyawa yang memiliki konstanta dielektrik yang rendah dan tidak dapat larut dalam air. Banyaknya minyak yang diperoleh dalam penelitian ini dikarenakan penggunaan pelarut nheksana.Heksana memiliki rentang titik didih yang cukup sempit sekitar 63-69 ${ }^{\circ} \mathrm{C}$ dan merupakan pelarut minyak yang sangat baik dalam hal kelarutan minyak dan mudah dipulihkan.

Minyak yang diperoleh kemudian di hitung rendemennya. Hasil rendemen minyak biji pala dapat dilihat pada Tabel 1 :

Tabel 1. Rendemen Minyak Biji Pala Dari Beberapa Ukuran Serbuk

\begin{tabular}{|c|c|c|}
\hline \multicolumn{2}{|c|}{ Jenis Sampel } & Rendemen(\%) \\
\hline \multirow{2}{*}{ Biji Pala } & 60 mesh & 39.61 \\
\cline { 2 - 3 } & 40 mesh & 37.52 \\
\cline { 2 - 3 } & 20 mesh & 28.09 \\
\hline
\end{tabular}

Berdasarkan Tabel 1 dapat dilihat bahwa semakin halus ukuran bahan, nilai rendemen yang dihasilkan makin baik. Tingginya rendemen yang terdapat pada ukuran serbuk 60 mesh dikarenakan, ukuran bahan yang kecil akan membuka jaringan dalam serbuk yangmenyebabkan jumlahminyak yang terekstrak lebih banyak dan proses difusi semakin cepat. Semakin halus serbuk pala maka semakin efisien karena semakin besar luas permukaan banyak kontak dengan pelarut sehingga semakin efisien proses ekstraksi.

Menurut Somaatmaja (1984), standar rendemen minyak biji pala dengan menggunakan pelarut air berkisar antara 2-15\%. Pada penelitian yang telah dilakukan, nilai rendemen berkisar antara 28,09 - 39,61 \%. Nilai rendemen yang tinggi disebabkan karena pelarut yang digunakan adalah pelarut n-heksana, dibandingkan menggunakan pelarut air. Karena minyak merupakan senyawa nonpolar yang tersusun atas rantai hidrokarbon panjang, demikian pula heksana yang merupakan senyawa nonpolar.

\section{Bilangan Asam}

Bilangan asam dari minyak biji pala hasil penelitian dapat dilihat pada Gambar 2.

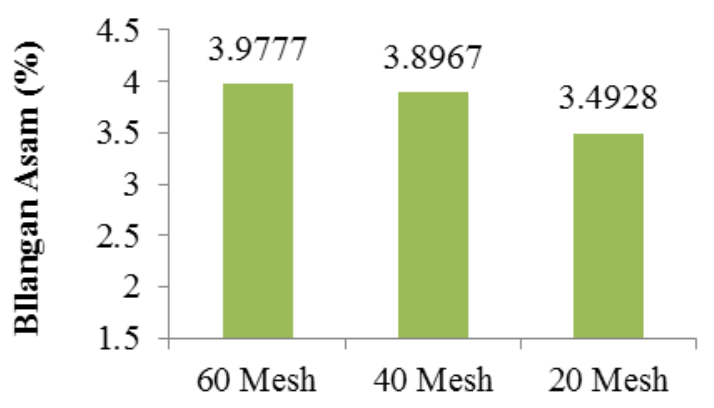

Ukuran Serbuk Biji Pala

Gambar 2. Bilangan asam minyak biji pala dari beberapa ukuran serbuk

Dari Gambar 2 menunjukkan bahwa semakin halus ukuran serbuk pada biji pala maka nilai bilangan asam yang dihasilkan akan naik. Daryono et al., (2014), mengatakan semakin kecil ukuran sampel dan lamanya waktu ekstraksi maka nilai bilangan asam akan semakin besar, ini dikarenakan waktu kontak dengan pelarut yang cukup lama 
sehinga membuat selaput pelindung minyak atsiri melunak dan mempermudahpenetrasi pelarut kedalam bahan baku. Bilangan asam pada minyak atsiri menandakan adanya kandungan asam organik pada minyak tersebut.

Pahan (2016) menyatakan pelarut heksan tidak hanya mengekstraksi trigliserida, tetapi juga asamasam lemak bebas, khususnya asam lemak oleat dan linoleat yang larut dalam pelarut nonpolar.Standar yang ditetapkan dalam (EOA) Essential Oil Association, standar bilangan asam pada minyak atsiri adalah maksimal 5. Pada penelitian yang telah dilakukan oleh Sipahelut (2012), nilai bilangan asam berkisar antara 3,71 $4,38 \%$. Sehingga minyak biji pala yang dibuat masih dalam taraf baik.

\section{Bilangan Peroksida}

Tingkat kerusakan minyak dapat diketahui dan biasa dinyatakan sebagai bilangan peroksida. Nilai PV (Peroxide value) hasil penelitian dapat dilihat pada Gambar 3.

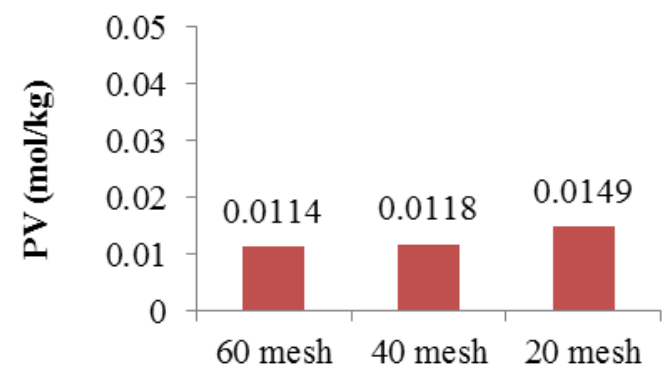

Ukuran Serbuk Biji Pala

Gambar 3. Nilai PV minyak biji pala dari beberapa ukuran serbuk

Gambar 3 menunjukkan bahwa nilai PV naik seiring dengan ukuran serbuk pada isolasi minyak dari biji pala yang semakin kasar. Menurut Rahardjo, (2006) bilangan peroksida yang tinggi merupakan indikator bahwa minyak sudah mengalami oksidasi, namun pada angka yang lebih rendah bukanselalu menunjukkan kondisi oksidasi yang masih dini. Angka peroksida rendah bisa disebabkan oleh laju pembentukan peroksida baru lebih kecil dibandingkan dengan laju degradasinya menjadi senyawa lain, mengingat kadar peroksida cepat mengalami degradasi dan bereaksi dengan zat lain.

Standar baku PV pada minyak pala belum ditetapkan. Namun hasil yang diperoleh telah sesuai dengan yang dispesifikasikan oleh FAO/WHO untuk edible oil yakni dibawah $10 \mathrm{~mol} / \mathrm{kg}$ (Adejumo et al., 2013). Sehingga minyak pala yang dibuat masih dalam taraf baik.

\section{Bilangan Ester}

Hasil penelitian bilangan ester dari minyak biji pala dapat dilihat pada Gambar 4:

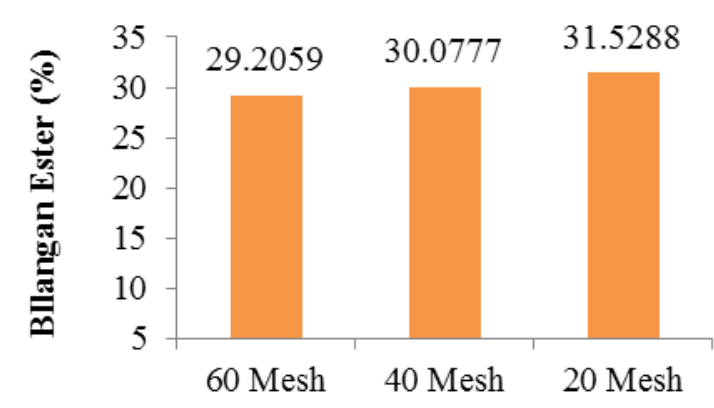

Ukuran Serbuk Biji Pala

Gambar 4. Nilai bilangan ester minyak biji pala dari beberapa ukuran serbuk

Gambar 4 menunjukkan bahwa nilai bilangan ester yang tertinggi dihasilkan dari minyak biji pala ukuran serbuk 20 mesh yaitu masing-masing $31,5288 \%$ sedangkan nilai bilangan ester terendah dihasilkan dari ukuran 60 mesh yaitu 29,2059\%. Ukuran serbuk yang lebih kecil memerlukan $\mathrm{HCl}$ yang banyakuntuk menetralkan larutan atau ditunjukan dengan warna merah tepat hilang. Reaksi yang terjadi adalah

$$
\mathrm{KOH}+\mathrm{HCl} \longrightarrow \mathrm{KCl}+\mathrm{H}_{2} \mathrm{O}
$$

Adanya bilangan ester pada minyak dapat menandakan bahwa minyak tersebut mempunyai aroma yang baik.Standar baku untuk bilangan ester pada minyak pala belum ditetapkan,namun sesuai penelitian yang telah dilakukan oleh Sipahelut (2012), nilai bilangan ester berkisar antara 29,04 $30,84 \%$. Maka hasil analisis yang dilakukan dalam penelitian ini dalam taraf aman.

\section{Kelarutan dalam Etanol $90 \%$}

Nilai kelarutan minyak biji pala dalam etanol merupakan indikasi dari kemampuan minyak pala melarut sempurna dalam alkohol.Nilai kelarutan minyak biji pala yang dianalisis dapat dilihat pada Tabel 2

Tabel 2. Hasil analisis kelarutan dalam etanol 90\% minyak biji pala dari beberapa ukuran serbuk

\begin{tabular}{|c|c|c|c|}
\hline & \multirow{2}{*}{ Sampel } & \multicolumn{2}{|c|}{ Kelarutan dalam etanol } \\
\hline & & I & II \\
\hline \multirow{3}{*}{$\begin{array}{l}\text { Biji } \\
\text { Pala }\end{array}$} & $\begin{array}{c}60 \\
\text { mesh }\end{array}$ & $\begin{array}{c}1: 0,6 \text { jernih, } \\
\text { seterusnya } \\
\text { keruh }\end{array}$ & $\begin{array}{c}1: 0,4 \text { jernih, } \\
\text { seterusnya } \\
\text { keruh }\end{array}$ \\
\hline & $\begin{array}{c}40 \\
\text { mesh }\end{array}$ & $\begin{array}{c}1: 0,7 \text { jernih, } \\
\text { seterusnya } \\
\text { keruh }\end{array}$ & $\begin{array}{c}1: 0,6 \text { jernih, } \\
\text { seterusnya } \\
\text { keruh }\end{array}$ \\
\hline & $\begin{array}{c}20 \\
\text { mesh }\end{array}$ & $\begin{array}{c}1: 0,8 \text { jernih, } \\
\text { seterusnya } \\
\text { keruh }\end{array}$ & $\begin{array}{c}1: 0,6 \text { jernih, } \\
\text { seterusnya } \\
\text { keruh }\end{array}$ \\
\hline
\end{tabular}

Berdasarkan pada Tabel 2 kelarutan dalam etanol pada konsentrasi 90\%, semakin kecil ukuran serbuk maka etanol yang diperlukan untuk menjernihkan larutan hanya sedikit. Guenther 
(1972) menyatakan bahwa semakin banyak kandungan senyawa oxygenated monoterpene( terpen-o) dalam minyak maka semakin tinggi kelarutan dalam alkohol dibandingkan senyawa terpene. Makin tinggi kandungan terpen, makin rendah daya larutnya karena senyawa terpen teroksigenasi merupakan senyawa non polar yang tidak mempunyai gugus fungsional. Namun pada perbandingan 1:1 setelah ditambahkan dengan etanol 90\% larutan menjadi keruh dengan dibandingkan kekeruhan yang terjadi dengan larutan pembanding. Penyebab larutan menjadi keruh setelah penambahan etanol 90\% adalah karena minyak hasil analisis mempunyai bilangan asam yang tinggi.

Menurut BSN baku mutu minyak pala yaitu 1:3. Hasil analisis yang didapat yaitu tidak sesuai standar baku mutu, sehingga minyak yang dihasilkan dari segi kelarutan dalam etanol $90 \%$ tidak baik digunakan.

\section{Kesimpulan}

Dari hasil penelitian yang telah dilakukan dapat disimpulkan bahwa : Nilai rendemen minyak biji pala yang tertinggi ditunjukkan oleh ukuran serbuk 60 mesh (39,61\%), diikuti 40 mesh $(37,52 \%)$, dan yang terendah pada 20 mesh (28,09\%). Nilai kualitas minyak biji pala untuk 60 ; 40; dan 20 mesh adalah secara berturut-turut : bilangan asam 3,9777; 3,8967; dan 3,4928\%. Bilangan peroksida 0,$0114 ; 0,0118$; dan 0,0149 mol/kg. Bilangan ester 29,2059; 30,0777; dan $31,5288 \%$. Kelarutan dalam etanol 90\% untuk 20 mesh mendekati nilai yang ditetapkan SNI, sedangkan untuk 40 dan 60 mesh tidak larut dalam etanol 90\%.
Daftar Pustaka

BSN (Badan Standarsasi Nasional). 2006. SNI Minyak Pala. BSN, Jakarta.

Daryono, E.D.,Aggriarida, T.P. dan Ahmad, I. 2014. Ekstraksi Minyak Atsiri pada Tanaman Kemangi dengan Pelarut n-Heksana. 9(1):1-7.

Guenther, E. 1972.Minyak Atsiri, Jilid IV A, a.b. Ketaren S, Universitas Indonesia Press, Jakarta.

Gunawan., M Triatmo., dan Rahayu A. 2003. Analisis Pangan : Penentuan Angka Peroksida dan Asam Lemak Bebas pada Minyak Kedelai dengan Variasi Menggoreng. JSKA.7(3).

Pahan, A.F.2016. Ekstraksi Minyak dan Resin Nyamplung (Calophyllum inophyllum) dengan Campuran Pelarut Heksan-Metanol. Fakultas Pertanian Institute Petanian Bogor, Bogor.

Rahardjo, B., Supriyanto., Marsono, Y., Supranto. 2006. Kinetika Perubahan Kadar 5Hydroxymethyl-2-Furtural (HMF) Bahan Makanan Berpati Selama Penggorengan. Jurnal Teknologi dana Industri Pangan. 17(2).

Sipahelut, S.G.2012. Karakteristik Kimia Daging Buah Pala (Muristica fragrans Houtt) Melalui Beberapa Cara Pengeringan dan Distilasi. Jurnal Agroforestri. 7(2) : 59-64.

Somaatmadja D. 1984. Penelitian Dan Pengembangan Pala Dan Fuli. Komunikasi No. 215. BBIHP,Bogor.

Sudarmadji, S., Bambang, H., dan Suhardi. 1997. Prosedur Analisa untuk Bahan Makanan dan Penelitian. Penerbit Liberty, Yogyakarta.

Sunanto, H. 1993. Budidaya Pala Komoditas Ekspor. Penerbit Kanisius, Yogyakarta. 